\title{
Intention to Adopt Mobile Marketing: An Exploratory Study in Labuan, Malaysia
}

\author{
Geoffrey Harvey Tanakinjal \\ Universiti Malaysia Sabah, Malaysia \\ Kenneth R. Deans \\ University of Otago, New Zealand \\ Brendan J. Gray \\ University of Otago, New Zealand
}

\begin{abstract}
The evolution of e-commerce also has brought with it a new marketing channel known as mobile marketing (m-marketing). Although mobile devices have been seen as a potential channel to reach consumers, effort is still needed to understand what influences intention to adopt mobile marketing. This study integrates innovation characteristics of the Innovation-Diffusion Theory (IDT), perceived risk, trustworthiness, and permissibility constructs to investigate what determines user intention to adopt mobile marketing. The proposed model in this study was empirically tested using data collected from a survey of mobile users. The research findings suggested that relative advantage of mobile marketing is the strongest influence in building consumers' intention decision to adopt mobile marketing. All other constructs were statistically significant in influencing behavioural intent to adopt mobile marketing. This study's findings support Rogers' (2003) perceived characteristics of innovation attributes that form a favourable or unfavourable attitude toward the innovation.
\end{abstract}

Keywords: Innovation diffusion theory, Perceived risk, Trustworthiness, Permissibility, Mobile marketing services 


\section{Introduction}

The American Marketing Association (AMA) has defined marketing as, "an organizational function and a set of processes for creating, communicating, and delivering value to customers and for managing customer relationships in ways that benefit the organization and its stakeholders" (AMA, 2004). Based on this definition, one area that has played an important role in providing alternatives, creating choices, and delivering value for the betterment of the modern lifestyle is technology. The marketing discipline has evolved where the environment consisting of consumers and service providers co-exist. Technology has also changed the way a product or a service from a provider reaches the consumer. According to Cox and Alderson (1948, p. 151), "the most acute marketing problems are precipitated by the facts of technological change." In this situation, the market analyst does not have the luxury of choice as to whether they will adopt a dynamic view, but at the very least he/she must take account of technological changes in marketing (Cox and Alderson, 1948). With technology change in mind, this paper will explore constructs that may influence the intention to adopt adoption an innovation (mobile marketing) from a user's perspective. According to Leppäniemi et al. (2006, p. 10), "mobile marketing is the use of the mobile medium as a means of marketing communications." Mobile marketing is sometimes used interchangeably with mobile advertising (Barnes and Scornavacca, 2004; Carroll et al., 2007; Tsang et al., 2004), but according to MMA (2007) the difference between mobile marketing and mobile advertising lies in the former being the vehicle for content delivery and direct response and the latter being the form of the message communicated through a consumer's handset. Key words in the above definition are mobile medium (e.g. mobile phones) and marketing communications (e.g. information, promotions, competitions, etc.). According to Pousttchi (2006), marketing experts consider that the mobile device is an extremely promising marketing tool to overcome the major challenges of getting time and the attention of consumers. Mobile device also provides opportunities to target messages for customers in more efficient ways than the present mass media (Barwise and Strong, 2002). The importance of mobile phones to end users has certainly been recognised by marketers, who view this as a communication channel with huge potential (Kavassalis et al., 2003; Norris, 2007; Nysveen et al., 2005). Although this innovation is good for marketers, mobile marketing also creates perceived problems of privacy and security risk for consumers. For consumers who have concerns over security and privacy in mobile marketing, service providers need to reassure consumers that transmission of their personal details are safe (Leek and Cristodoulides, 2009). In terms of cost, a local newspaper (Daily Express) reported that SMS scammers managed to get close to RM1.9 million from victims throughout the state of Sabah since 2006. According to Sabah's Commissioner of Police, Datuk Nor Rashid Ibrahim, RM26,000 was lost in 2006, while RM1.8 million went into the pockets of these conmen the following year ("RM 1.9m Sabah SMS rip-offs", 2009).

On the other hand, there is a possibility that the more exposed one is towards a particular/similar communication technology, the more confident one would be towards using the new marketing communication channel (Kavassalis et al., 2003; Norris, 2007; Nysveen et al., 2005). Although high mobile phone penetration rates do not necessarily mean high mobile marketing use, the potential of communicating 
marketing messages through mobile phones does exist. For example, in Malaysia, although the penetration rate of mobile phones in 2008 was 93.9 per cent $(26,126,000$ users) (MCMC), only seven percent of mobile phone subscribers had registered for mobile banking services, and only 13.7 percent accessed the Internet through their mobile phones (MCMC, 2007). According to a study conducted by Mutz (2005), people believe that, "brick and mortar" businesses are more trustworthy than electronic businesses (e-business). This view is shared by Siau and Shen (2003), who stated that while the internet creates unprecedented opportunities for initiating customer relationships, trust between the consumer and provider is an essential ingredient for the adoption of e-business. Trust is needed most when risks are perceived to be high, and many consumers perceive e-commerce as being highly risky (Mutz and Journals, 2005). Perceived risk is important in explaining consumer's behaviour, because consumers are more often motivated to avoid mistakes than maximising utility in purchasing (Mitchell, 1999). Despite many consumers being concerned with transaction security, merchant information, online privacy, and personal data, the problem of mistrust by consumers are often ignored by e-commerce providers (Wu and Wang, 2005). Thus, empirical investigation of privacy risk and personal data security is needed (Leppäniemi et al., 2006) in order to address consumers' perceived risk in technological adoption perspective. One area that may help in addressing the issue of privacy and security risk in e-commerce is obtaining consumers' permission (Kavassalis et al., 2003) to allow marketers to communicate with potential consumers and use consumers' data. Admissibility as a consequence of being permitted is known as permissibility (The American Heritage Dictionary of the English Language, 2003). It is important to stress that in the context of mobile marketing, trust, perceived risk (privacy and data security) and permissibility have been viewed identified in this study as important variables that need to be addressed by service providers to give consumers freedom from doubt (uncertainty) or assurance in adopting mobile marketing services.

\section{Significant of the Study}

Statistically, the mobile marketing industry grew from US\$4 billion to US\$16 billion from 2003 to 2005, serving over 500 million users world-wide (Carroll et al., 2007). Another study by ABI Research (2008) estimated that the global mobile marketing business is currently worth $\$ 3$ billion, and is projected to reach $\$ 19$ billion by 2011 . According to comScore M:Metrics, the downside of the high mobile phone penetration rate is the accompanying unwanted high text messaging or unsolicited Short Message Service (SMS) rate that is growing by 21.3 percent per year in the European Union (2008) alone. However, despite the increasing number of companies investing in mobile marketing campaigns, there is, as yet, little academic research on mobile marketing, and the implications of using this channel for marketing purposes are not fully understood (Bauer et al., 2005). Although mobile devices are promising marketing channels (Pousttchi and Wiedemann, 2006) mobile spam (i.e. unsolicited SMS messages) raises privacy concerns related to the utilization of the personal and location data used to personalize mobile marketing messages (Leppäniemi et al., 2006). Consumers may be reluctant to trust the innovation as a marketing 
communication channel because they perceive risk regarding the safety of their personal data and privacy. Users may also have perceived potential risks from immature technology (Wu and Wang, 2005). Hence, there is a need to conduct further research in understanding the factors that may influence the intention to adopt mobile marketing from a consumer's perspective particularly through Rogers' (1983) perceived innovation characteristics, perceived risk, trust, and permissibility.

\section{Literature Review}

Armstrong and Kotler (2009) define the adoption process of an innovation as the mental process through which an individual passes from first learning about an innovation to final adoption. However, this paper argues that final adoption can only be fully understood by looking into the factors that may influence intention decision to adopt mobile marketing. In recent years, researchers have begun to note the importance of gaining consumers' trust in relation to privacy and security for the mobile marketing communication channel to be accepted. Bauer (2005) further elaborated that trust is the prime prerequisite for consumers' willingness to permit the reception of advertising messages on their mobile phones and to provide personal data for the personalization of those messages. Risk is also related to the concept of trust (Mitchell, 1999) and in mobile marketing users tend to have concerns about data manipulation, unauthorized data access, and unwanted tracking of usage patterns (Bauer et al., 2005). In this thesis, perceived risk will be limited to personal data security and privacy risks because these are two important aspects in mobile marketing that need empirical investigation (Leppäniemi et al., 2006), and risk associated with mobile marketing is mainly perceived as one of data security (Bauer et al., 2005).

If mobile marketing is to be effective, end-user privacy must be respected (Kavassalis et al., 2003). Privacy issues are particularly sensitive with respect to mobile marketing due to the intimate nature of mobile devices (Brown, 2006). Besides worries of intrusion into one's private space, mobile spam raises privacy concerns related to the utilization of the personal and location data used to personalise mobile marketing messages (Leppäniemi et al., 2006). Constant messaging from the service providers may irritate consumers because of the ill timing and irrelevant content of the messages. Relevancy of a marketing message can only be determined by the consumer. Therefore, mobile marketers must interact with consumers and let them decide which types of marketing messages are permissible. By seeking consumers' inputs, marketers will not depend solely on random unsolicited messages, but can improve their targeting strategies by personalising communications.

User permission is also an important variable in mobile marketing due to consumers' fears of high levels of spam (Barnes and Scornavacca, 2004; Carroll et al., 2007). According to Kavassalis (2003), end-users' permission to opt-in with clear opt-out instructions must also be present if mobile marketing is to be effective. In this case, permissible mobile marketing messages may be seen as a strategy to reduce clutter 
and search costs for consumers and improving targeting precision for marketers (Krishnamurthy, 2001).

\section{Basic Concepts and Research Model and Hypotheses}

The scope of this paper was based on the Diffusion of Innovation (DoI) Theory (Rogers, 1983). According to Rogers (2003, p. 175), there are five perceived characteristics of innovation that can be used to form a favourable or unfavourable attitude toward an innovation, namely: relative advantage, compatibility, complexity, trialability, and observability. In mobile services research, although the DoI theory has been discussed in general by previous researchers, perceived characteristics of the innovation are often trimmed down based on Tornatzky and Klien's (1982) metaanalysis research findings (Teo and Pok, 2003; Wu and Wang, 2005) that recommend that relative advantage, complexity (ease of use) and compatibility were consistently related to adoption decisions. Moore and Benbasat (1991) argued that the original construct of observability was defined in a complex manner by Rogers (1983, p. 232) in which the results of an innovation are visible and communicable to others, and it also included the idea of the innovation being visible. Moore and Benbasat (1991) further explained that based on the definition of observability, it was decided in their study to split the construct and focus on each dimension independently; one dimension was named Results Demonstrability and the other, Visibility. Another argument regarding the observability characteristic was offered by Tornatzky and Klien (1982), who emphasized that it was unclear whether observability refers to cost or compatibility.

Based on these arguments, this paper will not include "observability" as one of perceived innovation characteristics because of various interpretations of the characteristic. This research will only maintain the original four out of five perceived innovation characteristics as proposed by Rogers (1983): relative advantage, complexity, compatibility, and trialability. Therefore the current research hypothesizes:-

$$
\begin{aligned}
& \mathrm{H}_{1} \text { : Relative advantage has a direct influence on intention decision } \\
& \mathrm{H}_{2} \text { : Compatibility has a direct influence on intention decision } \\
& \mathrm{H}_{3} \text { : Complexity has a direct influence on intention decision } \\
& \mathrm{H}_{4} \text { : Trialability has a direct influence on intention decision }
\end{aligned}
$$

Another area that may also contribute to understanding the adoption of mobile marketing services is trust. According to Siau and Shen (2003), trust is one of the major reasons influencing peoples' decisions in giving service providers their personal data via an electronic medium. This view is supported by Leppäniemi (2006), who indicated the need for empirical investigations into the factors that affect consumers' willingness to provide personal information, and granting permission to use this information in mobile marketing. Therefore the research hypothesizes: 
$\mathrm{H}_{5}$ : Trustworthiness has a direct effect on intention decision.

Perceived risk was also included in the model because according to Mitchell (1999), perceived risk is a necessary antecedent for trust to be operative and an outcome of trust building is a reduction in the perceived risk of the transaction or relationship. Hence, perceived risk is essential in the intention to adopt decision, and the current study proposes the following hypothesis:

$\mathrm{H}_{6}$ : Perceived risk has a direct effect on intention decision

Permissibility represents permission obtained from users to allow marketers to communicate relevant and anticipated marketing messages consumers. According to Godin (1999, p. 21), "permission marketing is an approach, which offers the consumer an opportunity to volunteer to be marketed". Reflecting these considerations the following hypothesis can be formulated.

$\mathrm{H}_{7 .}$ Permissibility has a direct effect on intention decision

Figure 1 Theoretical Research Framework and Hypothesis Paths

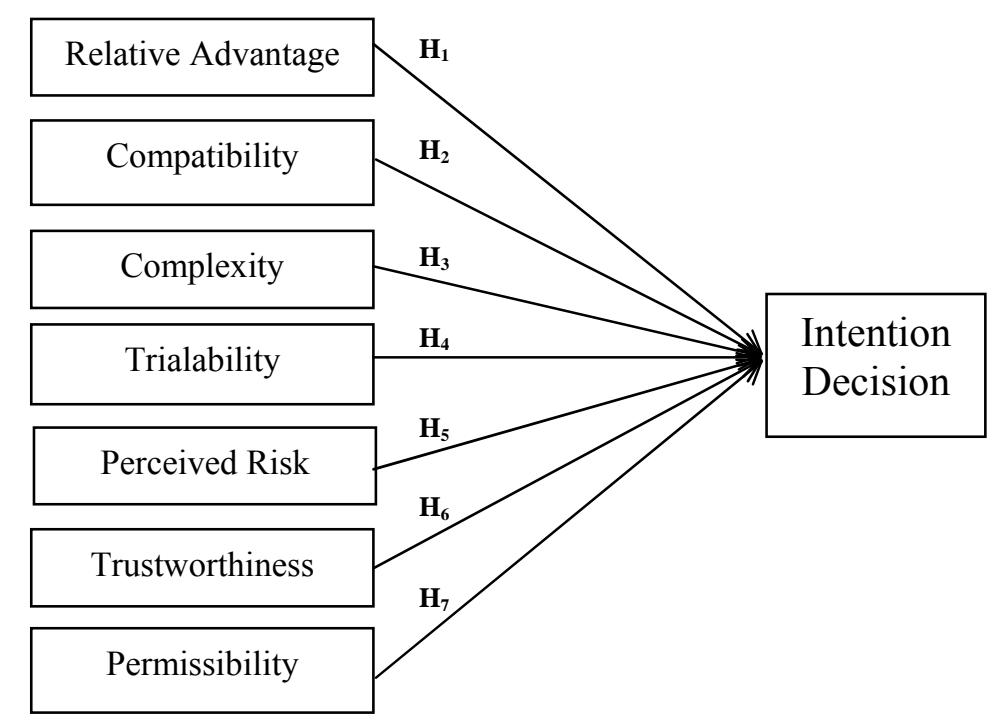

\section{Methodology}

Previous research was reviewed to ensure that a comprehensive list of measures were included. Those of 'relative advantage', 'compatibility', 'complexity', and 'trialability' were adopted from Moore and Benbasat (1991). Items for 'Intention decision' was adapted from Nysveen et al. (2005). New items were also proposed in 
this paper to measure trustworthiness, perceived risk and permissibility. Items representing each constructs can be found in Table 3. Once the initial questionnaire was completed, two rounds of comments by expert judges, senior academic lecturers, were conducted to refine the instrument. These expert judges' rounds enabled the researcher to gauge the clarity of the constructs, access whether the instrument was capturing the desired phenomena, and verify that important aspects had not been omitted. Some changes and amendments were made to the questionnaire. Feedback served as a basis for correcting, refining and enhancing the instruments scales. Some items were omitted from the questionnaire because they were found to represent essentially the same aspect with only slightly wording differences. Some items were modified to represent mobile marketing characteristics. The questionnaire consisted of 27 items measuring eight latent variables. Table 1 summarizes the definitions of variable.

\section{Table 1 Definition of Constructs}

\begin{tabular}{|c|c|c|}
\hline Variables & Definition of Construct & Adapted from \\
\hline $\begin{array}{l}\text { Permission } \\
\text { marketing }\end{array}$ & $\begin{array}{l}\text { A marketing approach that offers the consumer an } \\
\text { opportunity to volunteer to receive marketing } \\
\text { messages. }\end{array}$ & Godin, 1999 \\
\hline Perceived risk & $\begin{array}{l}\text { Consumers' subjective belief of suffering a loss in } \\
\text { pursuit of a desired outcome. Risk in this context is } \\
\text { related to subjective assessment of potential risk (i.e. } \\
\text { security and privacy) rather than "real world" } \\
\text { (objective) risk. }\end{array}$ & Bauer, 1960 \\
\hline Trust & $\begin{array}{l}\text { Emerges from the identification of a need that } \\
\text { cannot be met without the assistance of another and } \\
\text { some assessment of risk involved in relying on the } \\
\text { other to meet this need. Trust is a willing } \\
\text { dependency on another's action, but it is limited to } \\
\text { the area of need and subject to overt and covert } \\
\text { testing. The outcome of trust is an evaluation of the } \\
\text { congruence between expectations of the trusted } \\
\text { person (party) and actions. }\end{array}$ & $\begin{array}{l}\text { Hupcey et al., } \\
2001\end{array}$ \\
\hline $\begin{array}{l}\text { Relative } \\
\text { advantage }\end{array}$ & $\begin{array}{l}\text { the degree to which an innovation is perceived as } \\
\text { being better than the idea it supersedes. }\end{array}$ & $\begin{array}{l}\text { Rogers, 2003, p. } \\
229\end{array}$ \\
\hline Compatibility & $\begin{array}{l}\text { the degree to which an innovation is perceived as } \\
\text { consistent with the existing values, past experiences, } \\
\text { and the needs of potential adopters. }\end{array}$ & $\begin{array}{l}\text { Rogers, 2003, p. } \\
240\end{array}$ \\
\hline Complexity & $\begin{array}{l}\text { the degree to which an innovation is perceived as } \\
\text { being relatively difficult to understand and use. }\end{array}$ & $\begin{array}{l}\text { Rogers, 2003, p. } \\
257\end{array}$ \\
\hline Trialability & $\begin{array}{l}\text { the degree to which an innovation may be } \\
\text { experimented with on a limited basis. }\end{array}$ & $\begin{array}{l}\text { Rogers, 2003, p. } \\
258\end{array}$ \\
\hline $\begin{array}{l}\text { Intention to Use } \\
\text { (Decision Stage) }\end{array}$ & $\begin{array}{l}\text { when an individual (or other decision -making unit) } \\
\text { engages in activities that lead to a choice to adopt or } \\
\text { reject an innovation. }\end{array}$ & $\begin{array}{l}\text { Rogers, 2003, p. } \\
177\end{array}$ \\
\hline
\end{tabular}

The questionnaire was later pre-tested using Malaysian post-graduate candidates throughout New Zealand, the United Kingdom and Malaysia. Apart from completing 
the questionnaire, participants were also asked to comment on the language used, the accuracy of the translation and the relevance of the questions in the questionnaire. Based on their feedback some changes were made to the translation, such as using simple instructions in each of the sub-headings to help respondents easily understand the requirements of the questionnaire. A total of 87 questionnaires were distributed but only 61 questionnaires were returned, with 57 of them usable. Based on the pilot testing, several items were removed from the questionnaire to improve the reliability score. In the early stages of basic research, Nunnally (1967) suggests reliabilities of 0.50 to 0.60 would suffice and that increasing reliabilities beyond 0.80 is probably wasteful. Thus, for this paper the target level of minimum reliability was set in the 0.60 to 0.70 range.

Table 2 Reliability Analyses by Sections

\begin{tabular}{|l|c|c|}
\hline Section & $\begin{array}{c}\text { Cronbach's } \\
\text { Alpha }\end{array}$ & $\begin{array}{c}\text { Number of } \\
\text { Items }\end{array}$ \\
\hline Perceived Risk & .654 & 4 \\
\hline Permissibility & .790 & 4 \\
\hline Trust & .827 & 4 \\
\hline Relative Advantage & .906 & 3 \\
\hline Compatibility & .887 & 3 \\
\hline Complexity & .853 & 3 \\
\hline Trialability & .891 & 3 \\
\hline Intention Decision & .699 & 3 \\
\hline & & 27 items \\
\hline
\end{tabular}

\section{Data collection}

A total of 670 questionnaires were distributed to mobile phone users in Labuan, Malaysia. The return percentage was 57.46 percent (380 questionnaires), but only 341 questionnaires were usable.

\section{Statistical analysis}

All data analysis was conducted using SPSS v.15 and AMOS 7. A descriptive analysis will be used to portray a general picture of the survey respondents. The two main types of statistical analysis used in this research were the Factor Analysis Method and Structural Equation Modeling (SEM).

\section{Results}

For this paper, the KMO measure of sampling adequacy was 0.894 , indicating that the data clearly supported the use of factor analysis and suggesting that the data may be 
grouped into a smaller set of underlying factors. Eight major factors were identified, representing 58.337 percent of the total variance explained. The indicators in the model loaded highly on their constructs and were significant (factor loadings ranged from 0.53 to 0.91 ). Construct validity was further assessed by calculating Cronbach's alpha for each of the scales. The Cronbach's alpha measures included in the model ranged from 0.74 to 0.89 (Table 3 ). The alphas for the study constructs exceeded or equaled the threshold 0.70 (Nunnally, 1978). The composite reliability (CR) estimates the extent to which a set of latent construct indicators share in their measurement of a construct, whilst the average variance extracted (AVE) is the amount of common variance among latent construct indicators (Hair et al., 1998). The composite reliability also test evaluates the internal consistency of the measurement model (Karjaluoto et al., 2008). The CR values for all the constructs were above the recommended value of 0.70. According to Fornell and Larcker (1981) a model can be considered to have a good convergent validity if the AVE for each construct is greater than 0.50 , as this indicates that more of each construct is explained by its indicator than by other external influences. The AVE of the constructs in the model ranged from 0.30 to 0.74 . Perceived risk (0.49) and Decision Intention (0.30) have lower than 0.50 AVE value (Table 3 ).

Table 3 Factor Loadings and Assessment of Construct Reliability

\begin{tabular}{|c|c|c|}
\hline & ITEMS & Loading \\
\hline & Factor 1 - Complexity (CA = .89; CI=.89; $A V E=.74)$ & \\
\hline CPLX1 & Learning to use mobile marketing services would be easy for me. & .819 \\
\hline CPLX2 & $\begin{array}{l}\text { If I were to adopt mobile marketing services, it would be easy for } \\
\text { me to adapt. }\end{array}$ & .862 \\
\hline \multirow[t]{2}{*}{ CPLX3 } & $\begin{array}{l}\text { If I were to adopt mobile marketing services, it would be easy due } \\
\text { to my previous experience with mobile phone usage. }\end{array}$ & .705 \\
\hline & Factor 2 - Compatibility $(C A=.88 ; C I=.88 ; A V E=.72)$ & \\
\hline COM1 & $\begin{array}{l}\text { If I were to adopt mobile marketing services, it would be } \\
\text { compatible with my internet searching methods. }\end{array}$ & .671 \\
\hline COM2 & $\begin{array}{l}\text { If I were to adopt mobile marketing services, it would fit my } \\
\text { product and services information gathering style. }\end{array}$ & .825 \\
\hline \multirow[t]{2}{*}{ COM3 } & $\begin{array}{l}\text { If I were to adopt mobile marketing services, it would fit well with } \\
\text { the way I like to seek relevant product and services information. }\end{array}$ & .689 \\
\hline & Factor 3 - Trialability $(C A=.86 ; C I=.87 ; A V E=.69)$ & \\
\hline TRY1 & $\begin{array}{l}\text { Before deciding on whether or not to adopt mobile marketing } \\
\text { services, I would be able to use it on a trial basis. }\end{array}$ & .724 \\
\hline TRY2 & $\begin{array}{l}\text { Before deciding on whether or not to adopt mobile marketing } \\
\text { services, I would be able to test the suitability of the services. }\end{array}$ & .812 \\
\hline \multirow[t]{2}{*}{ TRY3 } & $\begin{array}{l}\text { I would be permitted to use mobile marketing services on a trial } \\
\text { basis long enough to see what it can do. }\end{array}$ & .719 \\
\hline & Factor 4 - Permissibility $(C A=.77 ; C I=.84 ; A V E=.63)$ & \\
\hline PM2 & $\begin{array}{l}\text { I would consider giving my permission to receive mobile } \\
\text { marketing messages if the messages are relevant. }\end{array}$ & .699 \\
\hline PM3 & $\begin{array}{l}\text { I would consider giving my permission to receive mobile } \\
\text { marketing messages if I anticipate the content of the message. }\end{array}$ & .697 \\
\hline PM4 & I would consider giving my permission to receive mobile & .716 \\
\hline
\end{tabular}




\begin{tabular}{|c|c|c|}
\hline & ITEMS & Loading \\
\hline & marketing messages if the messages are personalised. & \\
\hline & Factor 5 - Trustworthy $(C A=.76 ; C I=.81 ; A V E=.59)$ & \\
\hline T1 & $\begin{array}{l}\text { I consider mobile marketing is a reliable way to receive relevant } \\
\text { information. }\end{array}$ & .583 \\
\hline T3 & $\begin{array}{l}\text { Mobile marketing services are a trustworthy source of } \\
\text { personalised marketing messages. }\end{array}$ & .585 \\
\hline \multirow[t]{2}{*}{ T4 } & $\begin{array}{l}\text { Mobile marketing services are reliable because messages are up- } \\
\text { to-date. }\end{array}$ & .631 \\
\hline & Factor 6 - Relative Advantage $(C A=.88 ; C I=.89 ; A V E=.73)$ & \\
\hline RA1 & $\begin{array}{l}\text { If I were to adopt mobile marketing services, it would enable me } \\
\text { to get information more quickly. }\end{array}$ & .572 \\
\hline RA2 & $\begin{array}{l}\text { If I were to adopt mobile marketing services, the quality of my } \\
\text { information would improve. }\end{array}$ & .718 \\
\hline \multirow[t]{2}{*}{ RA3 } & $\begin{array}{l}\text { If I were to adopt mobile marketing services, it would enhance my } \\
\text { effectiveness on information gathering. }\end{array}$ & .742 \\
\hline & Factor 7 - Perceived Risk $(C A=.74 ; C I=.74 ; A V E=.49)$ & \\
\hline RISK1 & $\begin{array}{l}\text { It is safe to accept and reply to mobile marketing messages via } \\
\text { mobile phone. }\end{array}$ & .682 \\
\hline RISK3 & $\begin{array}{l}\text { There is no more privacy risk involved in receiving marketing } \\
\text { messages via mobile phone than there is when getting marketing } \\
\text { messages via email or TV advertisement. }\end{array}$ & .573 \\
\hline \multirow[t]{2}{*}{ RISK4 } & $\begin{array}{l}\text { I do not consider mobile marketing to be a privacy risk way to } \\
\text { receive marketing messages. }\end{array}$ & .667 \\
\hline & Factor 8 - Decision Stage $(C A=.70 ; C I=.56 ; A V E=.30)$ & \\
\hline DS1 & $\begin{array}{l}\text { I intend to accept mobile marketing messages occasionally from } \\
\text { my current service provider in the next } 6 \text { months. }\end{array}$ & .427 \\
\hline DS2 & $\begin{array}{l}\text { I intend to accept marketing messages from my current service } \\
\text { provider frequently in the next } 6 \text { months. }\end{array}$ & .406 \\
\hline DS3 & $\begin{array}{l}\text { I intend to use my mobile phone to get relevant marketing } \\
\text { messages in the next } 6 \text { months. }\end{array}$ & .843 \\
\hline
\end{tabular}

Table 4 Correlations and Square Root of Average Variance Extracted

\begin{tabular}{|c|c|c|c|c|c|c|c|c|c|}
\hline & AVE & 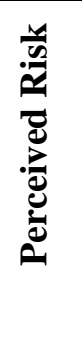 & 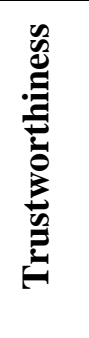 & 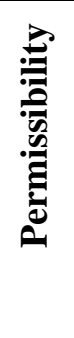 & 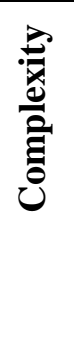 & 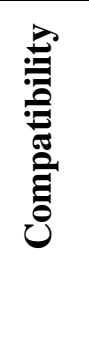 & 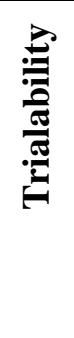 & 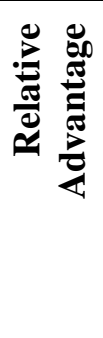 & $\begin{array}{l}\text { } \\
\\
\end{array}$ \\
\hline Perceived Risk & .49 & .700 & & & & & & & \\
\hline Trustworthiness & .59 & .708 & .768 & & & & & & \\
\hline Permissibility & .63 & .010 & .011 & .793 & & & & & \\
\hline Complexity & .74 & .247 & .337 & .223 & .860 & & & & \\
\hline Compatibility & .72 & .377 & .499 & .173 & .339 & .848 & & & \\
\hline
\end{tabular}




\begin{tabular}{|c|c|c|c|c|c|c|c|c|c|}
\hline & AVE & 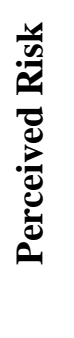 & 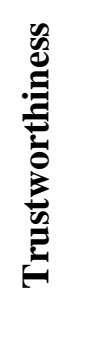 & 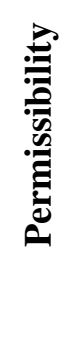 & 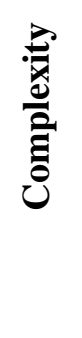 & 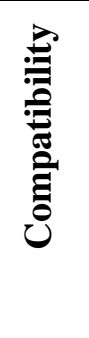 & 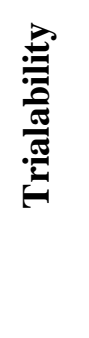 & 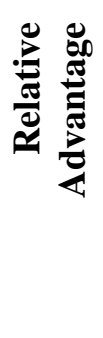 & 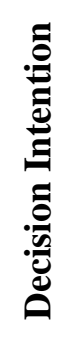 \\
\hline Trialability & .69 & .134 & .325 & .326 & .408 & .522 & .830 & & \\
\hline Relative Advantage & .73 & .512 & .587 & .289 & .331 & .623 & .445 & .854 & \\
\hline Decision Intention & .30 & .258 & .383 & .217 & .301 & .655 & .611 & .529 & .547 \\
\hline
\end{tabular}

To assess the discriminant validity of the model, tests were performed as to whether the square root of AVE for each construct is greater than the correlation with each other construct (Fornell and Larcker, 1981). Table 4 represents the square root of average variance extracted and the correlations between the constructs. As can be seen, the square root of AVE is greater than the correlation with any other construct except for Decision Intention construct. These indicate good discriminant validity of the model.

\section{Estimates and Fit Criteria}

For SEM, goodness-of-fit (GFI) indexes are used to evaluate the model in order to assess the model in terms of model fit and model parsimony (refer to Table 5). The GFI measures the percent of observed covariances explained by the covariances implied by the model, and the GFI should be equal or greater than 0.90 to accept the model (Gefen et al., 2000). For this paper the GFI is 0.907, above the recommended value of $>0.90$.

The Adjusted Goodness-of-Fit Index (AGFI) is adjusted for the degrees of freedom of a model relative to the number of variables, and should be above 0.80 (Chin and Todd, 1995; Segars and Grover, 1993). For this model, the AGFI was 0.888, above the recommended value of $>0.80$.

Bentler (1990) revised the NFI to consider sample size and proposed the comparative fit index (CFI). Although Bentler (1992, p. 401) stated that, "higher values indicate greater covariation accounted for, with excellent model having NFI values above 0.90 representative of a well fitting model", a revised cut-off value close to 0.95 has recently been advised ( $\mathrm{Hu}$ and Bentler, 1995) for CFI. The NFI value was 0.904, above the recommended value of $>0.90$, and the CFI value was 0.966 , above the cutoff value $>0.95$, suggesting a good fit between the hypothesized model and the sample data. 
The Tucker-Lewis index (TLI) yields values ranging from zero to 1.00 , with values close to 0.95 (for a large sample) being indicative of good fit (Byrne, 2001; Hu and Bentler, 1999). The TLI for the current model was 0.962.

For Root Mean Square Error of Approximation (RMSEA), a value less than 0.05 indicates good fit, and a value as high as 0.08 represents reasonable errors of approximation in the population (Browne and Cudeck, 1993). But MacCallum (1996, p. 134), "considers values in the range of 0.08 to 0.10 to indicate mediocre fit", and $\mathrm{Hu}$ (1999) suggested a value of 0.06 to be indicative of good fit between the hypothesized model and the observed data. This paper reports the index value for RMSEA to be within the recommended value (specifically, $<0.05$ ) at 0.038 , which indicates a good fit between the hypothesized model and the observed data.

\section{Table 5 Goodness-of-Fit Statistics}

\begin{tabular}{|l|c|c|}
\hline \multicolumn{1}{|c|}{ Statistic } & $\begin{array}{c}\text { Recommended } \\
\text { criteria }\end{array}$ & Value \\
\hline Goodness-of-fit index (GFI) & $>0.90$ & 0.907 \\
\hline Adjusted goodness-of-fit index (AGFI) & $>0.80$ & 0.888 \\
\hline Comparative Fit Index (CFI) & $>0.95$ & 0.966 \\
\hline Tucker -Lewis index (TLI) & $>0.95$ & 0.962 \\
\hline Normed fit index (NFI) & $>0.90$ & 0.904 \\
\hline Root mean square of approximation (RMSEA) & $<0.05$ & 0.038 \\
\hline
\end{tabular}

Source: AMOS 7.0 output.

\section{Hypothesis Testing}

Table 6 Summary of Research Findings

\begin{tabular}{|l|c|c|c|}
\hline \multicolumn{1}{|c|}{ Hypothesis } & $\begin{array}{c}\text { Influence } \\
\text { direction }\end{array}$ & $\begin{array}{c}\text { Critical } \\
\text { ratio }\end{array}$ & Findings \\
\hline $\begin{array}{l}\mathrm{H}_{1} \text {. Relative Advantage has a direct effect on } \\
\text { intention decision }\end{array}$ & + & $9.776^{* * *}$ & Supported \\
$\begin{array}{l}\mathrm{H}_{2} \text {. Compatibility has a direct effect on intention } \\
\text { decision }\end{array}$ & + & $9.324^{* * *}$ & Supported \\
$\begin{array}{l}\mathrm{H}_{3} \text {. Complexity has a direct effect on intention } \\
\text { decision }\end{array}$ & + & $7.840^{* * *}$ & Supported \\
$\begin{array}{l}\mathrm{H}_{4} \text {. Trialability has a direct effect on intention } \\
\text { decision }\end{array}$ & + & $7.878^{* * *}$ & Supported \\
$\begin{array}{l}\mathrm{H}_{5} \text { Perceived risk has a direct effect on intention } \\
\text { decision }\end{array}$ & + & $6.362^{* * *}$ & Supported \\
$\begin{array}{l}\mathrm{H}_{6} \text {. Trustworthiness has a direct effect on intention } \\
\text { decision }\end{array}$ & + & $7.482^{* * *}$ & Supported \\
$\begin{array}{l}\mathrm{H}_{7 .} \text { Permissibility has a direct effect on intention } \\
\text { decision }\end{array}$ & + & $6.116^{* * *}$ & Supported \\
\hline
\end{tabular}

The results of structural equation modeling are standardized maximum likelihood path coefficient for the hypothesized model. * Significant at the $p<0.1$ level, ** Significant at the $p<0.05$ level, $* * *$ Significant at the $p<0.01$ level. 
Figure 2 presents the significant structural relationship among the variables and standardized path coefficients. All the hypotheses for this paper were strongly supported and all standardised paths were significant $(> \pm 1.96)$ (refer to Table 6). For hypothesis 1 , the result indicated that relative advantage has a significant effect on the decision intention by consumers to adopt mobile marketing $(\beta=0.83)$. This indicates that users' relative advantage of a new innovation is an important determinant for users' decision intention to adopt mobile marketing. Compatibility, complexity, and trialability also have direct effects on intention decision with regression weight $(\beta)$ of $0.79,0.61$ and 0.63 , respectively. These findings support Rogers' (2003) perceived characteristics of innovation attributes where the above three constructs can be used to form a favourable or unfavourable attitude toward the innovation.

Figure 2 Structural Relationship among the Variables and Standardized Path Coefficients
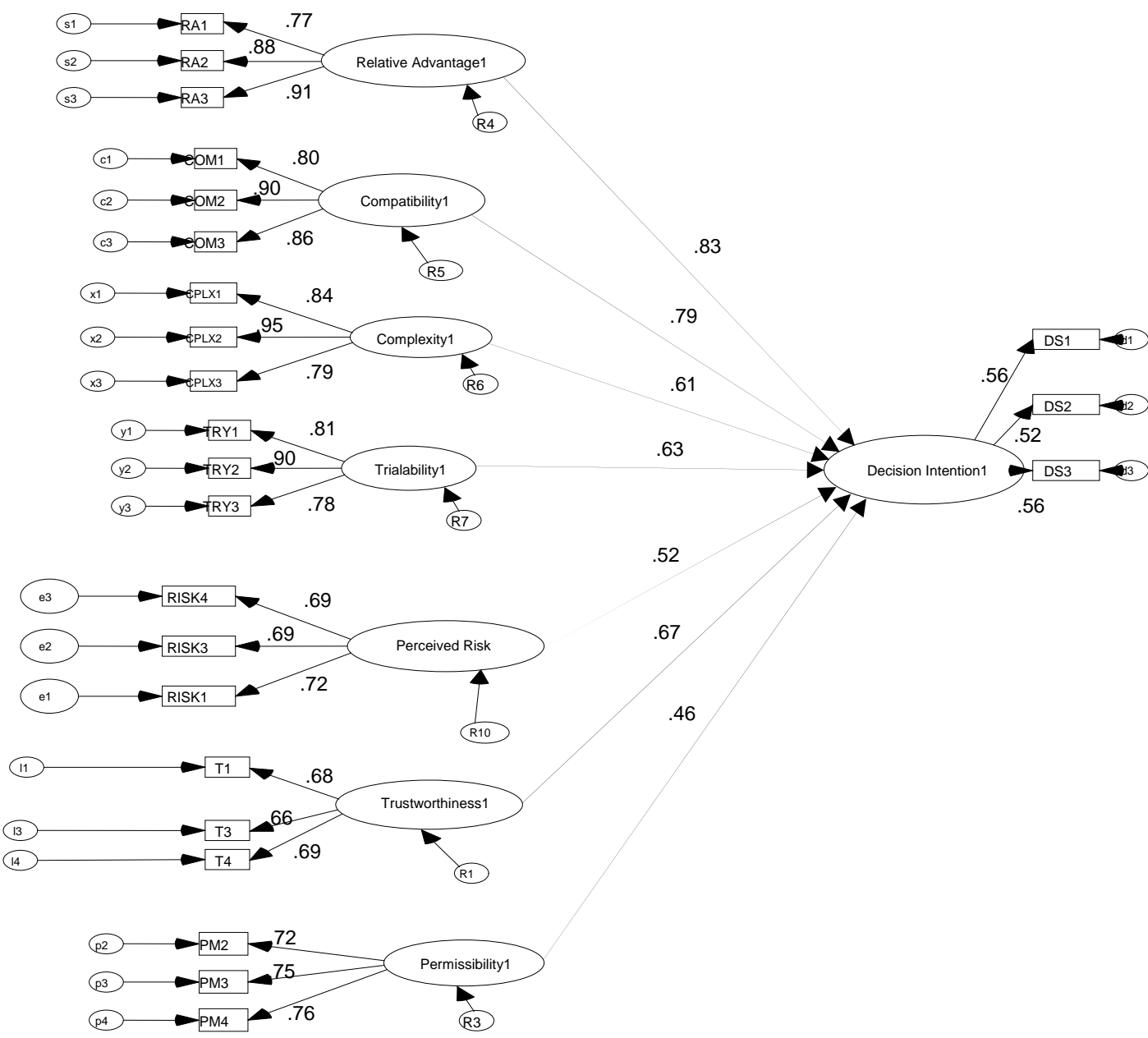
Perceived risk also registered a significant direct effect towards intention decision with regression weight of 0.52 in this study. This result was consistent with $\mathrm{Wu}$ and Wang's (2005) findings and they attributed their result to users' previous experience with online services which may imply that consumers are more aware of the existence of potential risk and have a better understanding of the mobile commerce context. This result also supports Ulivieri's (2004) argument that a consumer goes on doing something that initially seemed to be risky or dangerous but little by little she/he becomes more confident; it is a form of basic trust derived from habit and from the decreasing perceived probability of damage. According to Kim (2008), consumers are often faced with at least some degree of risk or uncertainty in using mobile technology, however risk is not the only factor consumers are sensitive to, but relates the perceived benefit that provides consumer with an incentive to use the mobile technology

Permissibility was statistically significant in influencing decision intention (c.r. = 6.116) with a regression weight of 0.46 . Through users' permission, companies can develop an iterative product development approach that can incorporate demand requirements while familiarizing the customer with the technology dimension of a mobile marketing campaign (Kavassalis et al., 2003). The significant relationship between permissibility and intention to adopt also supports Barwise and Strong's (2002) findings that consumers' explicit permission is essential for a high level of acceptance and satisfaction of mobile marketing.

Trustworthiness with a regression weight of 0.67 was also significant in influencing consumers' intentions to adopt mobile marketing. The nature of the innovation determines what specific type of relative advantage is important to the adopters (Rogers, 2003). At this stage respondents may perceive that by trusting on the service, they might receive better and up-to-date information about their interest/s and relating this information within their circle of friends. If mobile marketing is to be an effective and lucrative industry, it has to deliver relevant, requested (trusted), and interactive content to customers (Kavassalis et al., 2003).

\section{Research Limitation and Recommendation for Future Research}

First, the current research only looked at the adoption decision of mobile marketing services through one type of mobile device (i.e. mobile phones) and not through other mobile devices (i.e. PDAs, Palms, etc). Other consumers using other types of mobile devices may have a different response if they had been included in the study. For example, on October 24 2008, the Oprah Winfrey Show introduced "Kendall" by built by Amazon, which is a portable, wireless electronic book that could download about 7,000 books at half the price of the shelf price. Kendall is also capable of downloading newspapers and getting definitions of words instantly from the Internet at the user's convenience. New mobile devices will continue to be introduced; therefore this paper has limited its finding to mobile phones only. Second, the research only looked at one community (social system) to represent the adoption process by which an innovation is communicated through certain channel over time 
among members of a social system. In addition, owing to resource limitations the research did not survey respondents outside of the social system chosen for the study.

Focusing on the implications for future research data collected for this paper strongly suggest that perceived risk is more than just risk in general and should focus on data security and privacy concerns for mobile marketing research. Although a universallyagreed theoretical definition still eludes marketing academia for perceived risk, good models of perceived risk can only be judge on what the researcher is attempting to achieve by designing the model (Mitchell, 1999). Previous researchers may have used perceived risk in their models (Teo and Pok, 2003), but tend to treat perceived risk as a general construct (i.e. risk). Perceived risk was based on security and privacy risk faced by mobile phone users in m-marketing. The result suggested that low perceived risk was associated with $\mathrm{m}$-marketing when questioned regarding security and privacy issues faced by potential users of m-marketing. When perceived risk is low, significant relationship was found on trustworthiness of the service. In terms of perceived risk, then, low or high perception of specific risks (i.e. security and privacy) can be seen as an active process of engagement in the adoption process.

\section{Conclusion}

This paper explored the potential factors that may influence the intention of mobile phone users to adopt mobile marketing services through seven perceived characteristics namely; relative advantage, compatibility, complexity and trialability, perceived risk, trustworthiness and permissibility that may play important roles in determining consumer decision intention to adopt mobile marketing. Although the constructs in this paper have been represented by a strong direct significant relationship towards decision intention, nonetheless, future research should incorporate the Theory of Reasoned Action (TRA) or the Theory of Planned Behaviour (TPB) to better understand the innovation-decision process, because the study's proposed model did not allow the researcher to explore the effects of attitude and intention measurement to determine what factors amplify or disrupt the adoption process. 


\section{References}

The American Heritage Dictionary of the English Language (2003), 4th ed., Houghton Mifflin Company, Boston, MA.

Anonymous (2008a), "Security risks rise as phones become smarter". Retrieved from http://www.airwidesolutions.com/nov2508.html

Anonymous (2008b), "Study reveals increase in mobile phone spam. Retrieved 12/02/2009, from uSwitch.com: http://www.uswitch.com/news/mobilephones/20081126/study-revealsincrease-in-mobile-phone-spam.cmsx

Bagozzi, R. and Yi, Y. (1988), "On the evaluation of structural equation models", Journal of the Academy of Marketing Science, vol. 16, no. 1, pp. 74-94.

Banerjjee, S. (2008), "Marketing through mobile phone". Retrieved 12/02/2009, from domain-b.com: http://www.domain-

b.com/brand_dossier/marketing/20080522_mobile_phones.html

Barwise, P. and Strong, C. (2002), "Permission-based mobile advertising", Journal of Interactive Marketing, vol. 16, no. 1, pp. 14-24.

Bauer, H.H., Reichardt, T., Barnes, S.J. and Neumann, M.M. (2005), "Driving consumer acceptance of mobile marketing: A theoretical framework and empirical study", Journal of Electronic Commerce Research, vol. 6, no. 3, pp. 181-192.

Bauer, R.A. (1960), "Consumer behavior as risk taking" in R.S. Hancock (Ed.), Dynamic Marketing for A Changing World, American Marketing Association, Chicago, IL, pp. 389398.

Bentler, P.M. (1990), "Comparative fit indexes in structural models", Psychology Bulletin, vol. 107, no. 2, pp. 238-246.

Bentler, P.M. (1992), "On the fit of models to covariances and methodology to the bulletin", Psychology Bulletin, vol. 112, no. 3, pp. 400-404.

Brown, M. (2006), "Mobile marketing: Making a good connection”, Mobile Marketing Magazine. Retrieved 06/01/2007, from

http://www.mobilemarketingmagazine.co.uk/2006/09/making_a_good_c.html

Browne, M.W. and Cudeck, R. (1993), "Alternative ways of assessing model fit" in K.A. Bollen and J.S. Long (Eds.), Testing Structural Equation Models, Sage, Beverly Hills, CA, pp. 136-162.

Byrne, B.M. (2001), Structural equation modeling with AMOS, Lawrence Erlbaum Associates, Mahwah, NJ.

Carroll, A., Barnes, S.J., Scornavacca, E. and Fletcher, K. (2007), “Consumer perceptions and attitudes toward SMS advertising: Recent evidence from New Zealand", International Journal of Advertising, vol. 26, no. 1, pp. 79-98. 
Chin, W. and Todd, P. (1995), "On the use, usefulness, and ease of use of structural equation modeling in MIS research: A note of caution”, MIS Quarterly, pp. 237-246.

Gefen, D., Straub, D. and Boudreau, M. (2000), "Structural equation modeling and regression: Guidelines for research practice, Communication of AIS, vol. 1, no. 7, pp. 1-78.

Godin, S. (1999), Permission Marketing: Turning Strangers into Friends, and Friends into Customers, Simon \& Schuster, New York, NY.

Hibberd, M. (2007), "Put your message here", Mobile Communication International, pp. 4044.

Hu, L. and Bentler, P.M. (1995), "Evaluating model fit" in R.H. Hoyle (Ed.), Structural Equation Modeling: Concept, Issues and Application, Sage, Thousand Oaks, CA, pp. 76-99.

Hu, L. and Bentler, P.M. (1999), "Cut-off criteria for fit Indexes in covariance structure analysis: Conventional criteria versus new alternatives", Structural Equation Modeling, vol. 6, no. 1, pp. 1-55.

Hupcey, J.E., Penrod, J., Morse, J.M. and Mitcham, C. (2001), “An exploration and advancement of the concept of trust", Journal of Advanced Nursing, vol. 36, no. 2, pp. 282293.

Kavassalis, P., Spyropoulou, N., Drossos, D., Mitrokostas, E., Gikas, G. and Hatzistamatiou, A. (2003), "Mobile permission marketing: Framing the market inquiry", International Journal of Electronic Commerce, vol. 8, no. 1, pp. 55-79.

Kim, D.J., Ferrin, D. and Rao, H. (2008), "A trust-based consumer decision-making model in electronic commerce: The role of trust, perceived risk, and their antecedents", Decision Support Systems, vol. 44, no. 2, pp. 544-564.

Leppäniemi, M., Sinisalo, J. and Karjaluoto, H. (2006), “A review of mobile marketing research", International Journal of Mobile Marketing, vol. 1, no. 1, pp. 2-12.

MacCallum, R.C., Browne, M.W. and Sugawara, H.M. (1996), "Power analysis and determination of sample size for covariance structure modeling", Psychological Methods, vol. 1, no. 2, pp. 130-149.

Marriott, L. (2007), "Growing consumer interest in mobile marketing”. Retrieved 13/02/2009, from ClickZ: http://www.clickz.com/3624471

MCMC (2007), “Hand phone users survey 2007”. Retrieved 10/02/2009, from Suruhanjaya Komunikasi dan Multimedia Malaysia:

http://www.skmm.gov.my/facts_figures/stats/pdf/Handphone_Users_Survey_2007.pdf

MCMC (2008), "Q3 2008 communication and multimedia: Selected facts and figures". Retrieved 10/02/2009, from Malaysia Communication and Multimedia Commission: http://www.skmm.gov.my/mcmc/facts_figures/stats/pdf/Quarter3_2008.pdf

Mitchell, V.W. (1999), "Consumer perceived risk: Conceptualizations and models", European Journal of Marketing, vol. 33, no. 1-2, pp. 163-195. 
MMA (2007), “Understanding mobile marketing: Technology and reach". Retrieved 18/09/2007 from Mobile Marketing Association:

http://www.mmaglobal.com/uploads/MMAMobileMarketing102.pdf

Moore, G.C. and Benbasat, I. (1991), "Development of an instrument to measure the perceptions of adopting an information technology innovation", Information System Research, vol. 2, no. 3, pp. 192-222.

Mutz, D.C., and Journals, O. (2005), "Social trust and e-commerce", Public Opinion Quarterly, vol. 69, no. 3, pp. 393-416.

Norris, K. (2007), “May we? Mais oui? ” NZ Marketing, 10 March 2007.

Nunnally, J.C. (1967), Psychometric Theory, McGraw-Hill, New York, NY.

Nysveen, H., Pedersen, P.E. and Thorbjørnsen, H. (2005), "Intentions to use mobile services: Antecedents and cross-service comparisons", Journal of the Academy of Marketing Science, vol. 33, no. 3, pp. 330-346.

Pousttchi, K., and Wiedemann, D. (2006), A contribution to theory building for mobile marketing: Categorizing mobile marketing campaigns through case study research. Paper presented at the International Conference on Mobile Business, 26-27 June 2006, Copenhagen, Denmark.

Rogers, E.M. (1983), Diffusion of Innovations, 3rd ed., Free Press, New York, NY.

Rogers, E.M. (2003), Diffusion of Innovation, 5th ed., Simon \& Schuster, New York, NY.

Segars, A. and Grover, V. (1993), "Re-examining perceived ease of use and usefulness: A confirmatory factor analysis", MIS Quarterly, pp. 517-525.

Siau, K. and Shen, Z. (2003), "Building customer trust in mobile commerce", Communications of the ACM, vol. 46, no. 4, pp. 91-94.

Teo, T. and Pok, S. (2003), "Adoption of WAP-enabled mobile phones among Internet users", Omega, vol. 31, no. 6, pp. 483-498.

Tornatzky, L.G. and Klein, K.J. (1982), "Innovation characteristics and innovation adoptionimplementation: A meta-analysis of findings", IEEE Transactions on Engineering Management, vol. 29, no. 1, pp. 28-45.

Ulivieri, F. (2004), "Naïve approaches to trust building in web technologies", ISTC-Technical Report 15426B_2004, National Research Council, Institute for Cognitive Sciences and Technologies, Rome, Italy.

Wu, J.H. and Wang, S.C. (2005), "What drives mobile commerce? An empirical evaluation of the revised technology acceptance model", Information \& Management, vol. 42, no. 5, pp. 719-729. 